\title{
Plant Performance and Nutrient Losses during Containerized Landscape Shrub Production using Composted Dairy Manure Solids as a Peat Substitute in Substrate
}

\author{
A.L. Shober ${ }^{1,5}$, C. Wiese ${ }^{2}$, G.C. Denny ${ }^{1}$, C.D. Stanley ${ }^{3}$, and \\ B.K. Harbaugh ${ }^{4}$
}

ADDITIONAL INDEX WORDs. nursery crops, potting media, walter's viburnum, sandankwa viburnum, japanese privet

Summary. Concerns over the environmental impact and economics of harvesting sphagnum and reed-sedge peat have increased the desire to identify acceptable peat substitutes for use in container substrates. This preliminary study evaluated the use of composted dairy manure solids as a substitute for sphagnum or reed-sedge peat in container substrates for production of woody ornamental shrubs and assessed potential leaching of nutrients. Walter's viburnum (Viburnum obovatum), sandankwa viburnum (Viburnum suspensum), and japanese privet (Ligustrum japonicum) were grown in 3-gal plastic containers with seven substrates containing (by vol.) $60 \%$ pine bark, $10 \%$ sand, and $30 \%$ sphagnum peat $(S)$, reed-sedge peat $(R)$, and/or composted dairy manure solids (C). Substrate composition had no effect on plant quality ratings for any species, growth index (GI) of walter's viburnum, or shoot and root dry weight of walter's viburnum and japanese privet. However, the GI of japanese privet and sandankwa viburnum was the lowest when grown in substrates containing a high percentage of reed-sedge peat (0S:3R:0C). Substrate effects on average nitrate + nitrite nitrogen leachate losses were minimal over the 88-day leachate collection period. However, the substrate containing the highest proportions of composted dairy manure solids (0S:0R:3C) generally had the highest average ammonium nitrogen and dissolved reactive phosphorus losses compared with other substrates. All substrates tested as part of this study appeared to be commercially acceptable for production of container-grown woody ornamental shrub species based on growth and quality. However, average nutrient losses from containers differed depending on the peat or peat substitute used to formulate the substrates.

$\mathrm{R}$ ecent concerns over the environmental impact and costs of harvesting sphagnum and reed-sedge peat have generated interest in identifying alternative materials that can be used as a substitute for peat in container substrates. Researchers suggested that composted dairy cattle manure solids can be an acceptable substitute for peat in container substrate

University of Florida, IFAS, Gulf Coast Research and Education Center, 14625 CR 672, Wimauma, FL 33598

The work was supported by the Florida Agricultural Experiment Station and the Florida Department of Agriculture and Consumer Services.

The authors thank Nancy West, Gitta Shurberg, and Tim Davis of the University of Florida Gulf Coast REC for their assistance with data collection. We also thank Florida Wholesale Growers for donating plant material.

\section{${ }^{1}$ Assistant Professor}

${ }^{2}$ Research and Extension Assistant

${ }^{3}$ Professor

${ }^{4}$ Professor Emeritus

${ }^{5}$ Corresponding author. E-mail: alshober@ufl.edu.
(Gorodecki and Hadar, 1990; Li et al., 2009; Wang et al., 2004) because the physical and chemical properties of this compost are adequate to support plant growth (Li et al., 2009). Nutrient leaching [particularly nitrogen $(\mathrm{N})$ and phosphorus $(\mathrm{P})]$ from container substrates containing composted materials has not been studied and is a concern.

A number of factors affect the extent of leaching from container substrate including the substrate components (Wilson et al., 2009), species grown in the substrate (Cole and Newell, 1996), frequency of watering or rainfall (Broschat, 1995), volume of water applied (Huett, 1997; Huett and Morris, 1999; Yelanich and Biernbaum, 1994), and/or the addition of inorganic fertilizers (Beeson, 1996). Leaching from container substrates containing composted materials (e.g., composted yard waste and composted recycled paper) is variable. However, researchers have reported that some substrate combinations leached equal or less $\mathrm{N}$ [as nitrate $\left(\mathrm{NO}_{3}\right)-\mathrm{N}$ and ammonium $\left.\left(\mathrm{NH}_{4}\right)-\mathrm{N}\right)$ (Beeson, 1996; Cole and Newell, 1996) and P (Beeson, 1996) than a comparable peat-based substrate. leachedy, a substrate containing pine bark, peat, and sand at a ratio of $3: 1: 1$ produced less leachate $\mathrm{NH}_{4}-\mathrm{N}$ than a comparable substrate when peat was replaced with composted paper (Cole and Newell, 1996). However, few studies have evaluated the leaching potential of composted materials when used as a peat substitute in pine bark-based substrate formulations for the production of ornamental woody plants. The objectives of this study were to l) evaluate the use of composted dairy manure solids as a substitute for sphagnum or reed-sedge peat in container substrate on the growth and quality of walter's viburnum, sandankwa viburnum, and japanese privet and 2) assess the potential for $\mathrm{N}$ and $\mathrm{P}$ leaching from substrates during production by examining the nutrient content in leachate from pots.

\begin{tabular}{llll}
\hline $\begin{array}{l}\text { Units } \\
\begin{array}{l}\text { To convert U.S. to SI, } \\
\text { multiply by }\end{array}\end{array}$ & U.S. unit & SI unit & $\begin{array}{l}\text { To convert SI to U.S., } \\
\text { multiply by }\end{array}$ \\
\hline 0.01 & $\%$ & $\mathrm{~g} \cdot \mathrm{g}^{-1}$ & 100 \\
10 & $\%$ & $\mathrm{~g} \cdot \mathrm{kg}^{-1}$ & 0.1 \\
29.5735 & $\mathrm{fl} \mathrm{oz}$ & $\mathrm{mL}$ & 0.0338 \\
0.3048 & $\mathrm{ft}$ & $\mathrm{m}$ & 3.2808 \\
0.0283 & $\mathrm{ft}^{3}$ & $\mathrm{~m}^{3}$ & 35.3147 \\
3.7854 & gal & $\mathrm{L}$ & 0.2642 \\
25.4 & inch(es) & $\mathrm{mm}$ & 0.0394 \\
16.3871 & inch & $\mathrm{cm}^{3}$ & 0.0610 \\
1 & micron & $\mu m^{3}$ & 1 \\
1 & $\mathrm{mmho} / \mathrm{cm}$ & $\mathrm{dS} \cdot \mathrm{m}^{-1}$ & 1 \\
28.3495 & $\mathrm{oz}$ & $\mathrm{g}$ & 0.0353 \\
28,350 & $\mathrm{oz}$ & $\mathrm{mg}$ & $3.5274 \times 10^{-5}$ \\
6.8948 & $\mathrm{psi}$ & $\mathrm{kPa}$ & 0.1450 \\
$\left({ }^{\circ} \mathrm{F}-32\right) \div 1.8$ & ${ }^{\circ} \mathrm{F}$ & ${ }^{\circ} \mathrm{C}$ & $\left(1.8 \times{ }^{\circ} \mathrm{C}\right)+32$
\end{tabular}




\section{Materials and methods}

Formulation OF POTTING SUBSTRATE. Seven substrates were formulated by mixing 60\% (by vol.) pine bark (Florida Potting Soils, Orlando, FL) and 10\% (by vol.) sand (Sakrete multipurpose sand; Bonsal American, Charlotte, NC) with Canadian sphagnum peat $(S)$, Florida reed-sedge peat (R), and/or composted dairy manure solids (C) (30\% by vol.) in the following ratios: 1) 3S:0R:0C, 2 ) $0 \mathrm{~S}: 3 \mathrm{R}: 0 \mathrm{C}$, 3 ) 2S:0R:1C, 4 ) 0S:2R:1C, 5 ) 1S:0R: 2C, 6) 0S:1R:2C, and 7) 0S:0R:3C. Canadian sphagnum peat was purchased from Fafard (Apopka, FL) and Florida reed-sedge peat was purchased from Reliable Peat Co. (Okahumpka, FL). Li et al. (2009) reported a pH of 3.9 and 6.9, an electrical conductivity (EC) of 0.32 and $0.31 \mathrm{dS} \cdot \mathrm{m}^{-1}$ and a carbon-to-nitrogen $(\mathrm{C}: \mathrm{N})$ ratio of 56.8 and 18.3 for Canadian sphagnum peat and Florida reed-sedge peat (respectively) from the same source purchased at about the same time as our material. Composted dairy manure solids (Agrigy Co., Clearwater, FL) generated at a Lake Okeechobee facility were screened, composted in a large rotary drum composter at temperatures up to $65^{\circ} \mathrm{C}$ for $3 \mathrm{~d}$, and allowed to cure in static piles (Nordstedt and Sowerby, 2003). Li et al. (2009) reported a $\mathrm{pH}$ of 6.9 , an $\mathrm{EC}$ of 4.8 $\mathrm{dS} \cdot \mathrm{m}^{-1}$, and a $\mathrm{C}: \mathrm{N}$ ratio of 15.1 for composted dairy manure solids from the same source that were received at about the same time as our material. A bulk sample of sphagnum peat, reedsedge peat, and composted dairy manure solids from the sources noted was ground and sieved to pass a 0.42 $\mathrm{mm}$ screen and analyzed for total $\mathrm{N}$ and $\mathrm{P}$. The $\mathrm{pH}$ and $\mathrm{EC}$ of each substrate were measured using a $1: 2$ substrate-to-deionized water extract (Mylavarapu, 2009). Before planting, commercially available dolomitic lime was used to adjust substrate $\mathrm{pH}$ of substrates containing 3S:0R:0C, OS: 3R:0C, 2S:0R:1C, and 1S:0R:2C from $\mathrm{pH} 3.5,5,4.2$, and 4.7 , respectively, to pH 6.5.

Plant materials and experiMENTAL DESIGN. Three landscape shrub species, walter's viburnum, sandankwa viburnum, and japanese privet, were transplanted on 21 June 2007 from plugs (received 12 June 2007) into 3-gal pots. A single plug of walter's viburnum (one cutting per plug), sandankwa viburnum (three cuttings per plug), and japanese privet (three cuttings per plug) were transplanted per pot. Japanese privet were grown in the greenhouse for a period of $124 \mathrm{~d}$ after planting (DAP); walter's viburnum and sandankwa viburnum were grown in the greenhouse for 200 DAP. Additionally, each substrate treatment included four pots containing substrate mixes only (no plant material). Plant and substrate only pots were fertilized (as a topdress) with 71 $\mathrm{g} /$ pot of a $15 \mathrm{~N}-3.9 \mathrm{P}-10 \mathrm{~K}$, coated, slow-release, 4-month fertilizer (Osmocote Plus; Scotts, Marysville, $\mathrm{OH}$ ) on 25 June 2007. Plants were irrigated with potable well water [no measureable $\mathrm{NO}_{3}-\mathrm{N}, \mathrm{NH}_{4}-\mathrm{N}$, or dissolved reactive $\mathrm{P}$ (DRP)] using a drip irrigation system that was regulated to 15 psi. Each 3 -gal pot was outfitted with a single, adjustable-flow dripper (Shrubbler ${ }^{\circledR} 360^{\circ}$; Antelco Corp., Longwood, FL) that was set to water at the same rate. The irrigation schedule was created to ensure that plants would have adequate water for optimum growth, with initial rates based on measurements of the volume of water required to saturate the substrates in a 3 -gal pot containing no plant material. The initial irrigation run time was set to deliver $\approx 2.85 \pm$ $0.05 \mathrm{~L}$ of water per plant per irrigation event. Emitters and/or irrigation run time were adjusted weekly to increase the irrigation volume delivered to each pot to meet the transpiration needs of the growing plants. Irrigation events were initiated at 0900 HR on days when the substrate surface in most pots $(>\mathbf{5 0} \%)$ was dry. All pots were irrigated for the same duration to ensure that irrigation volume was applied consistently to all pots. While the irrigation schedule was not specifically designed to produce leachate, variability in substrate water-holding capacity between treatments and individual pot variability resulted in generation of leachate from pots (mean leachate volume = $182 \pm 44 \mathrm{~mL}$ per pot per day).

Plant measurements and evalUATION. Plant growth measurements and evaluations were conducted on all plant replicates once plants reached marketable size (124 DAP for japanese privet and 200 DAP for walter's viburnum and sandankwa viburnum) based on the Florida grades and standards for shrubs, trees, and groundcovers
(Florida No. 2 minimum grade) (Florida Department of Agriculture and Consumer Services, 1998). Plant quality was visually rated on a scale of $1-5$ as follows: 1 = unmarketable, dead plant; 2 = unmarketable, below average quality, significant dieback or pest damage; 3 = marketable, average quality, moderate dieback or pest damage; 4 = marketable, above average quality, minimal dieback or pest damage; and $5=$ marketable, excellent quality, no dieback or pest damage. Plant growth index (GI) was used as a quantitative indicator of plant growth and was calculated for each plant as GI (cubic meters) $=H \times$ $W 1 \times W 2$, where $H$ is the plant height (meters), $W 1$ is the widest width of the plant (meters), and W2 is the width perpendicular to the widest width (meters). Shoot biomass was determined by removing all plant tissue at the base and root biomass was collected by washing the substrate from the roots. Shoots and roots were dried to a constant weight at $105^{\circ} \mathrm{F}$ (minimum 48-h drying time) and the dry weight (grams) was recorded.

LeACHATE COLLECTION AND ANALYSIS. Leachate was allowed to drain freely into a thick plastic collection bucket positioned under each pot. The buckets were tightly fitted to the pots to reduce the potential for the evaporation of leachate between collection events. Pots were also elevated to prevent them from sitting in the standing leachate water. Leachate was collected from each pot one day after planting and then weekly until 17 Sept. 2007 (88 DAP). Total volume of leachate was recorded weekly and a subsample was collected biweekly for nutrient analysis. Leachate that was not saved for nutrient analysis was discarded each week. Leachate was thoroughly mixed and a $100-\mathrm{mL}$ sample of unfiltered leachate was passed through $0.45-\mu \mathrm{m}$ membrane filters. Filtered samples were stored frozen until they were analyzed for $\mathrm{NO}_{3}+$ nitrite $\left(\mathrm{NO}_{2}\right)-\mathrm{N}$ [U.S. Environmental Protection Agency (USEPA), 1993a], $\mathrm{NH}_{4}-\mathrm{N}$ (USEPA, 1993b), and DRP (Pote and Daniel, 2009) using a discrete analyzer (AQ2; Seal Analytical, Burgess Hill, UK). Nutrient loads from each pot (in milligrams) were determined by multiplying the concentration of $\mathrm{NO}_{3}+\mathrm{NO}_{2}-\mathrm{N}, \mathrm{NH}_{4}-$ $\mathrm{N}$, and DRP with the volume of leachate collected from each pot. 
Statistical analysis. The experiment was designed as a randomized complete block design with seven substrate treatments applied randomly to five plant replicates within each species. Data were analyzed separately for each plant species. Plant quality data were analyzed using the PROC GLIMMIX program in SAS (version 9.2; SAS Institute, Cary, NC) with the multinomial distribution and the $\mathrm{Cu}^{-}$ mulative logit link function. Plant GI, dry root weight, and dry shoot weight data were analyzed using the PROC MIXED procedure in SAS (version 9.2). Pairwise comparisons for GI, dry root weight, and dry shoot weight data were completed on the leastsquares means of the data using Tukey's honestly significant difference (HSD) test with a significance level of $\alpha=0.05$.

Leachate samples with concentrations of $\mathrm{NO}_{3}+\mathrm{NO}_{2}-\mathrm{N}, \mathrm{NH}_{4}-\mathrm{N}$, and DRP below the detection limit $(\mathrm{MDL} \times 2.5)$ were assigned a value of $0.5 \times$ the detection limit. Leachate DRP loads were cube-root transformed and leachate $\mathrm{NH}_{4}-\mathrm{N}$ and $\mathrm{NO}_{3}+\mathrm{NO}_{2}-\mathrm{N}$ were log transformed. All transformed load data were analyzed using PROC GLIMMIX in SAS (version 9.2) using a repeated measures model with substrate treatment as a fixed effect and block as a random effect; this model pooled load data from each pot overall sampling dates. A block-diagonal covariance matrix with identical first order autoregressive structure $[\operatorname{ar}(1)]$ on each block was specified. This structure incorporated correlation for all observations occurring from the same experimental unit. All data were checked for normality by examining histogram and normality plots of the conditional residuals. Analysis of transformed load data revealed a significant substrate $\times$ collection date interaction; however, further analysis of data by leachate collection date revealed consistent trends related to substrate effect on leachate nutrient loads over time. Consistent trends and the preliminary nature of the data presented indicated that it was appropriate to evaluate how substrate formulation affected average nutrient leaching loads over the entire study period using the repeated measures model. All pairwise comparisons of nutrient load data were completed on the least-squares means of the transformed data using Tukey's
HSD test with a significance level of $\alpha=0.05$. Arithmetic means are reported for nutrient loads in the text and tables.

\section{Results and discussion}

Plant Quality AND GROWTH. Plant quality ratings were unaffected by substrate composition for any of the evaluated plant species (data not shown). Substrate composition also had no effect on the GI of walter's viburnum (mean GI $=0.14 \mathrm{~m}^{3}$ ) or shoot or root dry weight of walter's viburnum $($ mean $=49.2$ and $30.5 \mathrm{~g}$, respectively) or japanese privet $($ mean $=$ 48.3 and $30.5 \mathrm{~g}$, respectively). These results were similar to those of Shober et al. (2010), who reported no differences in the quality, shoot dry weight, or root dry weight of coleus (Solenostemon scutellarioides) and marigold (Tagetes patula) grown for 5 weeks in substrates containing varying percentages of peat (reed-sedge or sphagnum) and/or composted dairy manure solids with perlite and vermiculite. Additionally, Li et al. (2009) reported no differences in shoot or root dry weight of golden pothos (Epipremnum aureum) or 'Florida Spire' fig (Ficus benjamina) when grown in substrate containing varying percentages of peat (reed-sedge or Canadian) or composted dairy manure solids with perlite and vermiculite.

In contrast, the GI of sandankwa viburnum and japanese privet was influenced by substrate composition (Fig. 1). Sandankwa viburnum shrubs planted in the 3S:0R:0C substrate had greater GI $\left(0.24 \mathrm{~m}^{3}\right)$ than those shrubs grown in the 0S:3R:0C substrate $\left(0.09 \mathrm{~m}^{3}\right)$ or the $0 \mathrm{~S}: 2 \mathrm{R}: 1 \mathrm{C}$ substrate $\left(0.08 \mathrm{~m}^{3}\right)$. Shrubs grown in the 2S:0R:1C substrate also produced greater GI $\left(0.23 \mathrm{~m}^{3}\right)$ than those shrubs grown in the $0 \mathrm{~S}: 2 \mathrm{R}: 1 \mathrm{C}$ substrate. Similarly, japanese privet shrubs grown in the $0 \mathrm{~S}: 2 \mathrm{R}: 1 \mathrm{C}$ or OS:3R:0C media exhibited the lowest GI $\left(0.12\right.$ or $0.10 \mathrm{~m}^{3}$, respectively); however, the GI of japanese privet grown in these two substrate combinations was only significantly less than shrubs grown in the $1 S: 0 \mathrm{R}: 2 \mathrm{C}$

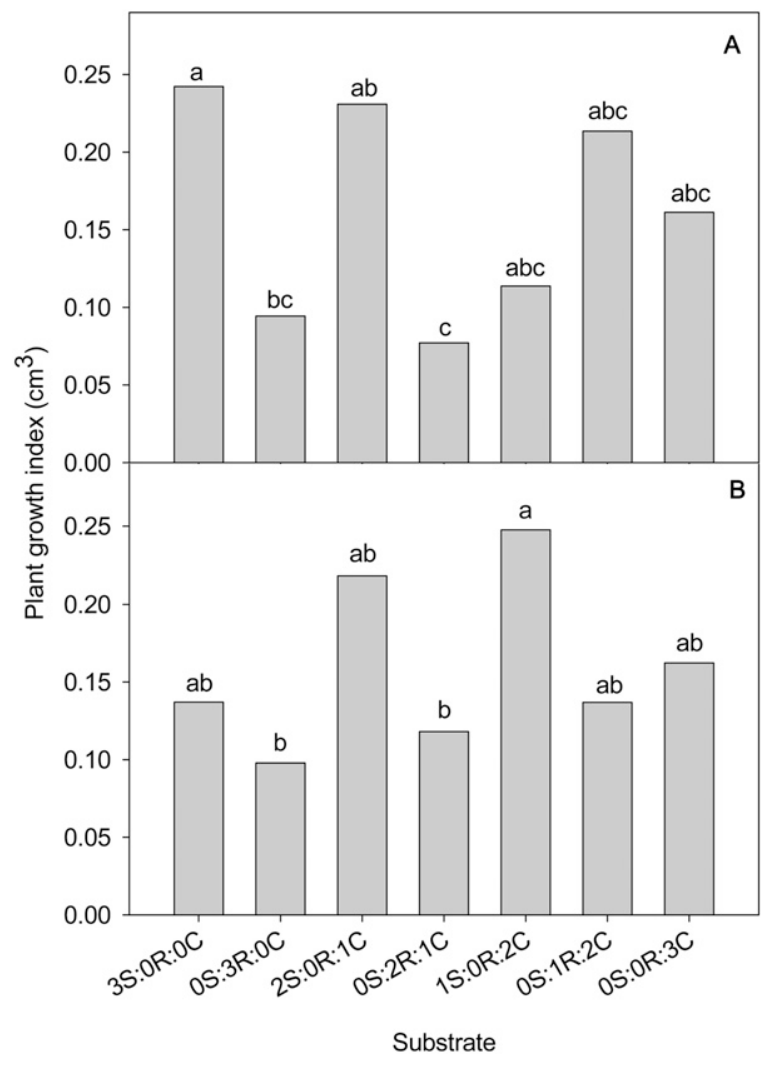

Fig. 1. Growth index ( $n=5)$ of (A) sandankwa viburnum and (B) japanese privet grown from plugs in substrates containing varying proportions of Canadian sphagnum peat (S), Florida reed-sedge peat (R), or composted dairy manure solids (C), each with $60 \%$ pine bark and $10 \%$ sand. Mean separation by Tukey's honestly significant difference test at $P \leq 0.05 ; 1 \mathrm{~cm}^{3}=0.0610 \mathrm{inch}^{3}$. 
substrate $\left(0.25 \mathrm{~m}^{3}\right)$. Substrate-induced differences in the shoot and root dry weight occurred only with sandankwa viburnum (Fig. 2), where shrubs grown in the 3S:0R:0C substrate produced greater shoot dry weight $(42.4 \mathrm{~g})$ than those shrubs grown in 0S:3R:0C, 1S:0R:2C, or 0S:2R:1C (37.1, 37.2, and $39.6 \mathrm{~g}$, respectively).

The differences in GI, shoot dry weight, and root dry weight for sandankwa viburnum and japanese privet (GI only) reported in our study did not result in noticeable differences in shrub quality. In all cases where substrate composition influenced plant growth, plant performance was reduced in substrates containing reedsedge peat (Figs. 1 and 2). Reduced GI of sandankwa viburnum and japanese privet may have been due to differences in the water-holding capacity or porosity of the substrates containing reed-sedge peat as compared with substrates containing sphagnum peat and composted dairy manure solids. Other researchers have reported decreased growth of ornamental bedding plants in reed-sedge peat-based substrates compared with plants grown in substrate formulated with sphagnum peat or coconut coir (Meerow, 1994) or a media combining reed-sedge peat and sphagnum peat (Abad et al., 1989). Abad et al. (1989) reported that air-dried reedsedge peat had low plant available water ( $11.24 \%$ by vol.), which is lower than the recommended optimal range for bedding plant substrates $(24 \%$ to $40 \%$ by volume). Similarly, Meerow (1994) found that reed-sedge peat based potting substrate had higher air porosity and lower water-holding capacity than media containing the same percentage of sphagnum peat or coconut coir at the beginning of their study. However, Meerow (1994) also noted that air-porosity had decreased and water-holding capacity had increased in the reed-sedge peatbased media by the completion of the study (3-5 months depending on species).

In general, the results of shrub growth and quality that we reported were similar to those of other studies that have evaluated the growth of ornamental plants on a substrate comprising some percentage of composted

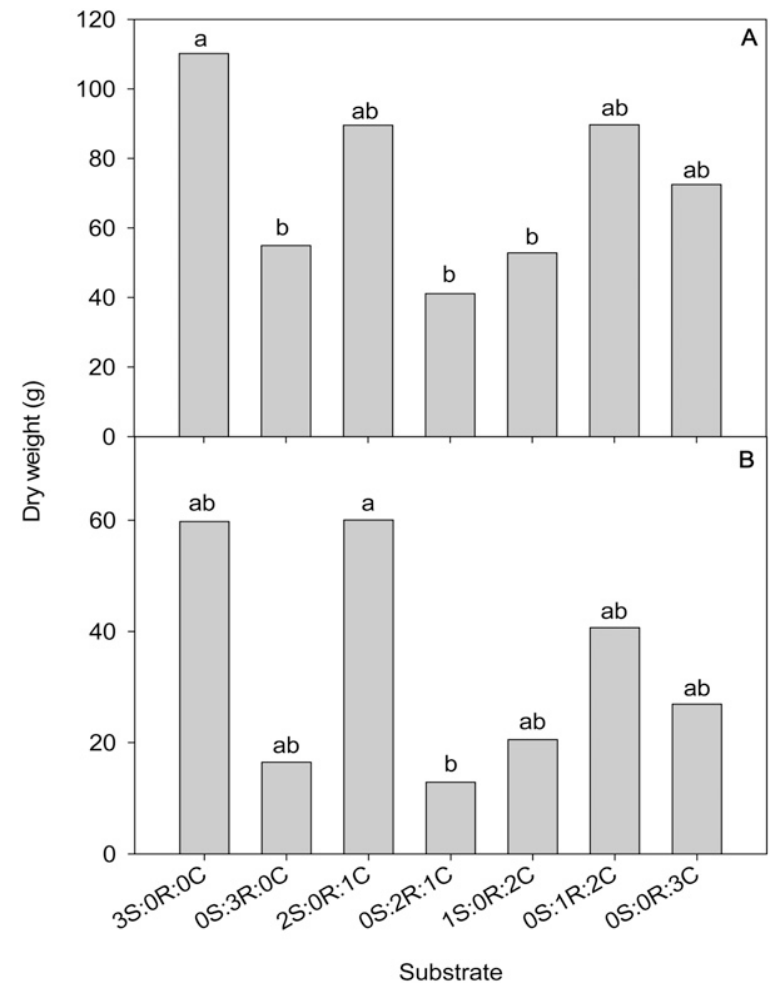

Fig. 2. Sandankwa viburnum (A) shoot dry weight and (B) root dry weight $(n=5)$ for plants grown from plugs in substrates containing varying proportions of Canadian sphagnum peat (S), Florida reed-sedge peat $(\mathrm{R})$, or composted dairy manure solids (C), each with $60 \%$ pine bark and $10 \%$ sand. Mean separation by Tukey's honestly significant difference test at $P \leq 0.05 ; 1 \mathrm{~g}=0.0353 \mathrm{oz}$. cattle manure as a substitute for sphagnum or reed-sedge peat ( $\mathrm{Li}$ et al., 2009; Raviv et al., 2005; Shober et al., 2010; Wang et al., 2004). Differences in shrub growth between substrate treatments that did not result in significant visible differences in aesthetic plant quality would not likely be of concern to growers and nursery professionals. Therefore, we suggest that all substrates examined as part of this study provided acceptable growth and would be suitable for use during the commercial production of ornamental landscape shrubs.

Leachate $\mathbf{N}$ LOAds. Substrate effects on mean $\mathrm{NO}_{3}+\mathrm{NO}_{2}-\mathrm{N}$ loads leached over the 88-d sampling period were minimal, with no reported substrate effects on mean leachate $\mathrm{NO}_{3}+\mathrm{NO}_{2}-\mathrm{N}$ loads for japanese privet, sandankwa viburnum, or containers filled with substrate only (no plant) (Table 1). The only substrate effect was noted for walter's viburnum, where the 0S:1R:2C substrate leached slightly less $\mathrm{NO}_{3}+\mathrm{NO}_{2}-\mathrm{N}$ on average than other substrates (Table $\mathrm{l}$ ). Based on mean total leachate data from the 88-d sampling period, no substrate was more or less likely to leach $\mathrm{NO}_{3}+$ $\mathrm{NO}_{2}-\mathrm{N}$ during the first $88 \mathrm{DAP}$.

Mean $\mathrm{NH}_{4}-\mathrm{N}$ loads leached over the 88 -d sampling period was significantly different among treatments as a result of substrate composition (Table 1), where substrate containing the highest proportion of composted dairy manure solids (i.e., OS:0R:3C) on average leached more $\mathrm{NH}_{4}-\mathrm{N}$ than other substrates for all species (Table 1). However, the mean $\mathrm{NH}_{4}-\mathrm{N}$ load leached from pots containing the 0S:0R:3C substrate was not significantly different from the mean load leached from the 1S:0R:2C substrate when sandankwa viburnum was grown or containers were without plants (substrate only) (Table 1). Additionally, there were no significant differences between the $\mathrm{NH}_{4}-\mathrm{N}$ load collected from pots containing the $0 \mathrm{~S}: 0 \mathrm{R}: 3 \mathrm{C}$ or $0 \mathrm{~S}: 2 \mathrm{R}: 1 \mathrm{C}$ substrates when growing walter's viburnum (Table 1).

We hypothesize that the trend for higher leachate $\mathrm{NH}_{4}-\mathrm{N}$ loads from the 0S:0R:3C substrate was due to higher concentrations of total $\mathrm{N}$ in the composted dairy manure solids (12.2 $\mathrm{g} \cdot \mathrm{kg}^{-1}$ ) compared with the sphagnum or reed-sedge peat (3.8 and $9.2 \mathrm{~g} \cdot \mathrm{kg}^{-1}$, respectively). Higher 
Table 1. Mean leachate nitrate + nitrite nitrogen $\left(\mathrm{NO}_{3}+\mathrm{NO}_{2}-\mathrm{N}\right)$, ammonium $\mathrm{N}\left(\mathrm{NH}_{4}-\mathrm{N}\right)$, and dissolved reactive phosphorus (DRP) loads $(n=5)$ collected over 12 weeks from woody ornamental plant species grown in 3-gal (11.4-L) containers with substrates composed of varying proportions of Canadian sphagnum peat $(S)$, Florida reed-sedge peat $(\mathrm{R})$, or composted dairy manure solids $(\mathrm{C})$.

\begin{tabular}{lccc}
\hline Substrate & $\begin{array}{c}\mathrm{NO}_{3}+\mathrm{NO}_{2}-\mathrm{N} \text { load } \\
(\mathbf{m g} / \text { pot })^{\mathrm{z}}\end{array}$ & $\begin{array}{c}\mathrm{NH}_{4}-\mathrm{N} \text { load } \\
(\mathbf{m g} / \mathbf{p o t})\end{array}$ & $\begin{array}{c}\text { DRP load } \\
(\mathbf{m g} / \text { pot })\end{array}$ \\
\hline \multicolumn{2}{c}{ Japanese privet } \\
3S:0R:0C & $10.8 \mathrm{a}^{\mathrm{y}}$ & $0.45 \mathrm{c}$ & $1.86 \mathrm{~cd}$ \\
0S:3R:0C & $13.1 \mathrm{a}$ & $0.61 \mathrm{c}$ & $0.91 \mathrm{~d}$ \\
2S:0R:1C & $9.73 \mathrm{a}$ & $0.54 \mathrm{bc}$ & $4.81 \mathrm{bc}$ \\
0S:2R:1C & $14.5 \mathrm{a}$ & $0.63 \mathrm{bc}$ & $4.02 \mathrm{bc}$ \\
1S:0R:2C & $9.09 \mathrm{a}$ & $0.54 \mathrm{bc}$ & $7.98 \mathrm{~b}$ \\
0S:1R:2C & $11.2 \mathrm{a}$ & $0.69 \mathrm{~b}$ & $7.24 \mathrm{~b}$ \\
0S:0R:3C & $11.2 \mathrm{a}$ & $1.30 \mathrm{a}$ & $29.1 \mathrm{a}$
\end{tabular}

\begin{tabular}{lccc} 
& \multicolumn{2}{c}{ Sandankwa viburnum } \\
3S:0R:0C & $11.4 \mathrm{a}$ & $0.28 \mathrm{c}$ & $1.69 \mathrm{~d}$ \\
0S:3R:0C & $15.0 \mathrm{a}$ & $0.22 \mathrm{c}$ & $0.36 \mathrm{e}$ \\
2S:0R:1C & $23.6 \mathrm{a}$ & $0.49 \mathrm{bc}$ & $2.60 \mathrm{~cd}$ \\
0S:2R:1C & $16.4 \mathrm{a}$ & $0.75 \mathrm{bc}$ & $2.35 \mathrm{~cd}$ \\
1S:0R:2C & $13.9 \mathrm{a}$ & $0.63 \mathrm{ab}$ & $7.62 \mathrm{~b}$ \\
0S:1R:2C & $8.24 \mathrm{a}$ & $0.46 \mathrm{bc}$ & $4.19 \mathrm{bc}$ \\
0S:0R:3C & $11.7 \mathrm{a}$ & $1.21 \mathrm{a}$ & $34.7 \mathrm{a}$
\end{tabular}

\begin{tabular}{llll}
\multicolumn{4}{c}{ Walter's viburnum } \\
3S:0R:0C & $6.73 \mathrm{ab}$ & $0.32 \mathrm{bc}$ & $1.09 \mathrm{~cd}$ \\
0S:3R:0C & $14.1 \mathrm{a}$ & $0.26 \mathrm{c}$ & $0.56 \mathrm{~d}$ \\
2S:0R:1C & $10.3 \mathrm{a}$ & $0.22 \mathrm{bc}$ & $3.30 \mathrm{bc}$ \\
OS:2R:1C & $17.0 \mathrm{a}$ & $0.79 \mathrm{ab}$ & $3.55 \mathrm{bc}$ \\
1S:0R:2C & $8.28 \mathrm{a}$ & $0.36 \mathrm{bc}$ & $7.28 \mathrm{~b}$ \\
0S:1R:2C & $5.79 \mathrm{~b}$ & $0.43 \mathrm{bc}$ & $5.14 \mathrm{~b}$ \\
OS:0R:3C & $8.15 \mathrm{ab}$ & $0.82 \mathrm{a}$ & $26.0 \mathrm{a}$
\end{tabular}

\begin{tabular}{lccc} 
& \multicolumn{3}{c}{ Noplant } \\
3S:0R:0C & $10.3 \mathrm{a}$ & $0.38 \mathrm{~b}$ & $1.68 \mathrm{~d}$ \\
0S:3R:0C & $14.6 \mathrm{a}$ & $0.30 \mathrm{~b}$ & $0.40 \mathrm{e}$ \\
2S:0R:1C & $11.8 \mathrm{a}$ & $0.34 \mathrm{~b}$ & $5.42 \mathrm{bc}$ \\
0S:2R:1C & $19.0 \mathrm{a}$ & $0.32 \mathrm{~b}$ & $3.95 \mathrm{c}$ \\
1S:0R:2C & $10.4 \mathrm{a}$ & $0.53 \mathrm{ab}$ & $8.23 \mathrm{~b}$ \\
0S:1R:2C & $13.4 \mathrm{a}$ & $0.37 \mathrm{~b}$ & $6.56 \mathrm{bc}$ \\
0S:0R:3C & $8.14 \mathrm{a}$ & $1.04 \mathrm{a}$ & $34.9 \mathrm{a}$ \\
\hline
\end{tabular}

${ }^{2}$ Nutrient loads from each pot were determined by adjusting the concentration of $\mathrm{NO}_{3}+\mathrm{NO}_{2}-\mathrm{N}, \mathrm{NH}_{4}-\mathrm{N}$, or DRP with the volume of leachate collected from each pot; $1 \mathrm{mg}=3.5274 \times 10^{5} \mathrm{oz}$.

${ }^{y}$ Mean separation for each species and collection date on least squares means of transformed data by Tukey's honestly significant difference test at $P \leq 0.05$.

concentrations of total $\mathrm{N}$ in the composted dairy manure solids may mean that the 0S:0R:3C substrate contained more potentially mineralizable $\mathrm{N}$ than the other substrate formulations. Because organic $\mathrm{N}$ must first be converted by microbes to $\mathrm{NH}_{4}{ }^{+}$, it is probable that $\mathrm{NH}_{4}-\mathrm{N}$ in substrate exceeded plant needs and led to leaching of $\mathrm{NH}_{4}-\mathrm{N}$ from the pots. Additionally, storage of leachate at ambient greenhouse temperatures for 7 $\mathrm{d}$ before collection may have increased the $\mathrm{NH}_{4}-\mathrm{N}$ concentration and load leached from each pot. An increase in
$\mathrm{NH}_{4}-\mathrm{N}$ concentrations was reported by Busch and McGinley (2010) when agricultural runoff samples were stored at $35^{\circ} \mathrm{C}$ before analysis. The authors suggested the increased $\mathrm{NH}_{4}-\mathrm{N}$ was due to greater mineralization of organic $\mathrm{N}$ due to microbial activity in the warm temperatures. Despite the increased leaching of $\mathrm{NH}_{4}-\mathrm{N}$ from pots containing the 0S:0R:3C substrate, $\mathrm{NH}_{4}-\mathrm{N}$ loads from all substrates were an order of magnitude lower than $\mathrm{NO}_{3}+\mathrm{NO}_{2}-$ $\mathrm{N}$ leached.

LEACHATE DISSOLVED REACTIVE $\mathbf{P}$ LOADs. Trends in average DRP leachate load over the 88 -d collection period were consistent for all evaluated species and pots containing substrate only (no plant). On average, the 0S:0R:3C substrate produced greater leachate DRP load than all other substrates through 88 DAP (Table 1). Over the study period, average DRP loads from leached substrates containing a mix of composted dairy manure solids and sphagnum peat or reed-sedge peat were intermediate between the 0S:0R:3C substrate and the 0S:3R:0C and 3S:0R:0C substrates (Table 1). The trend for higher average DRP loads from substrates containing higher proportions of composted dairy manure solids was likely due to higher concentrations of total $\mathrm{P}$ in the composted dairy manure solids $\left(3.9 \mathrm{~g} \cdot \mathrm{kg}^{-1}\right)$ compared with the sphagnum or reed-sedge peat (1.1 and $2.2 \mathrm{~g} \cdot \mathrm{kg}^{-1}$, respectively). The elevated concentrations of total $\mathrm{P}$ in the composted dairy manure solids can likely be attributed to the use of high $\mathrm{P}$ dietary supplements (specifically calcium phosphate minerals) in dairy feed, which are excreted from the animal and end up in manure (Shober et al., 2006; Toor et al., 2005).

\section{Conclusions}

We hypothesize that the reported substrate effects on the average nutrient loads leached through 88 DAP were likely a direct result of differences in the chemical properties of the sphagnum peat, reed-sedge peat, and composted dairy manure solids; however, all the substrates we evaluated produced acceptable shrub growth and quality as reported in other studies, suggesting that all substrates would be suitable for use during the commercial production of ornamental landscape shrubs. Additionally, we suggest that the nutrient leaching would probably not prohibit the use of composted dairy manure solids as a component of container substrates based on the results of our preliminary research. However, it is important to note that our observations are limited to trends over the 88-d sample collection period because total load data were not available.

The unavailability of total load data precludes us from making any comment on trends in nutrient leaching past the 88 - $\mathrm{d}$ collection period. As such, further research is needed to 
confirm if reported nutrient leaching trends would persist over the entire production period (124 DAP for japanese privet and 200 DAP for walter's viburnum and sandankwa viburum. Despite these limitations, we suggest that producers should carefully manage fertilizers to account for differences in nutrient content of substrate components like peat and peat alternatives to reduced nutrient leaching. Management of fertilizers should occur with the understanding that further research is needed to determine if a proportionate reduction in fertilization would affect plant growth or quality when shrubs are produced in substrates containing composted dairy manure solids as a peat substitute.

\section{Literature cited}

Abad, M., V. Noguera, J. Martinez-Corts, M.D. Martinez-Herrero, and F. Fornes. 1989. Physical and chemical properties of sedge peat-based media and their relation to plant growth. Acta Hort. 238:45-56.

Beeson, R.C. 1996. Composted yard waste as a component of container substrates. J. Environ. Hort. 14:115-121.

Broschat, T.K. 1995. Nitrate, phosphate, and potassium leaching from containergrown plants fertilized by several methods. HortScience 30:74-77.

Busch, D. and P. McGinley. 2010. The impact of sample holding time on nutrient forms in agricultural runoff. 2 Aug. 2010 . <http://www.usawaterquality.org/ conferences $/ 2010 / \mathrm{PDF} \% 27 \mathrm{~s} /$ Busch.pdf $>$.

Cole, J.C. and L. Newell. 1996. Recycled paper influences container substrate physical properties, leachate mineral content, and growth of rose-of-sharon and forsythia. Hort Technology 6:79-83.

Florida Department of Agriculture and Consumer Services. 1998. Grades and standards for nursery plants. Div. Plant
Ind., Florida Dept. Agr. Consumer Serv., Tallahassee, FL.

Gorodecki, B. and Y. Hadar. 1990. Suppression of Rhizoctonia solani and Scerotium rolfsii diseases in container media containing composed separated cattle manure and composed grape marc. Crop Prot. 9:271-274.

Huett, D.O. 1997. Fertiliser use efficiency by containerised nursery plants. 2 . Nutrient leaching. Aust. J. Agr. Res. 48:259-265.

Huett, D.O. and S.C. Morris. 1999. Fertiliser use efficiency by containerised nursery plants. 3. Effect of heavy leaching and damaged fertiliser prills on plant growth, nutrient uptake, and nutrient loss. Aust. J. Agr. Res. 50:259-265.

Li, Q., J. Chen, R.D. Caldwell, and M. Deng. 2009. Cowpeat as a substitute for peat in container substrates for foliage plant propagation. HortTechnology 19: 340-345.

Meerow, A.W. 1994. Growth of two subtropical ornamentals using coir (coconut mesocarp pith) as a peat substitute. HortScience 29:1484-1486.

Mylavarapu, R.S. 2009. UF/IFAS Extension soil testing laboratory (ESTL) analytical procedures and training manual. Univ. Florida Inst. Food Agr. Sci. Circ. 1248:19.

Nordstedt, R.A. and M.E. Sowerby. 2003. Final report for demonstration of on-site, in vessel dairy manure digestion. Univ. Florida Inst. Food Agr. Sci., Dept. Agr. Biol. Eng., Gainesville, FL.

Pote, D.H. and T.C. Daniel. 2009. Dissolved phosphorus in water samples, p. 110112. In: J.L. Kovar and G.M. Pierzynski (eds.). Methods of phosphorus analysis for soils, sediments, residuals and waters. U.S. Dept. Agr., Coop. State Res. Educ. Ext. Serv., Southern Ext. Res. Activity Info. Exchange Group 17, Southern Coop. Ser. Bul. No. 406.

Raviv, M., Y. Oka, J. Katan, Y. Hadar, A. Yogev, S. Medina, A. Krasnovsky, and H.
Ziadna. 2005. High-nitrogen compost as a medium for organic container-grown crops. Bioresour. Technol. 96:419-427.

Shober, A.L., D.L. Hesterberg, J.T. Sims, and S. Gardner. 2006. Characterization of phosphorus species in biosolids and manures using XANES spectroscopy. J. Environ. Qual. 35:1983-1993.

Shober, A.L., C. Wiese, G.C. Denny, C.D. Stanley, B.K. Harbaugh, and J. Chen. 2010. Plant performance and nutrient losses during containerized bedding plant production using composted dairy manure solids as a peat substitute in substrate. HortScience 45:1516-1521.

Toor, G.S., B.J. Cade-Menun, and J.T. Sims. 2005. Establishing a linkage between phosphorus forms in dairy diets, feces, and manures. J. Environ. Qual. 34: 1380-1391.

U.S. Environmental Protection Agency. 1993a. Method 353.2. Determination of nitrate-nitrite nitrogen by automated colorimetry. Environ. Monitoring Systems Lab., Office Res. Dev., U.S. Environ. Protection Agency, Cincinnati.

U.S. Environmental Protection Agency. 1993b. Method 350.1. Determination of ammonia nitrogen by semi-automated colorimitry. EPA-600/4-79-020, Environ. Monitoring Systems Lab., Office Res. Dev., U.S. Environ. Protection Agency, Cincinnati.

Wang, P., C.M. Changa, M.E. Watson, W.A. Dick, Y. Chen, and H.A.J. Hoitink. 2004. Maturity indices for composted dairy and pig manures. Soil Biol. Biochem. 36:767-776.

Wilson, S.B., K.L. Muller, P.C. Wilson, M.R. Incer, P.J. Stoffella, and D.A. Graetz. 2009. Evaluation of new container media for aglaonema production. Commun. Soil Sci. Plant Anal. 40:2673-2687.

Yelanich, M.V. and J.A. Biernbaum. 1994. Fertilizer concentration and leaching affect nitrate-nitrogen leaching from potted poinsettia. HortScience 29:874-875. 